$$
\text { "اللغات وجلة بحوث }
$$

\title{
خرق مبدأ الكم الحواري فى ثلاثية الحب لحسن البندارى
}

\section{*سارة محمد مصطةى}

د/ آلاءع عبد الغفار هلال

| (أد/ طارق سعد شلبي***

المستخلص

تناول هذا البحث خرق مبدأ الكم الحواري في ضوء مبادئ جر ايس، ووصل إلى عدة نتائج، هي: - يرجع الفضل لجر ايس في تصور مبادئ الاستلز ام الحواري وتفصيلها، ووضع الأسس المنهجية لهذا

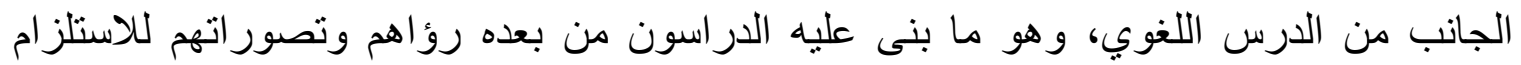

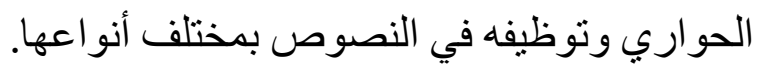
- يتحقق الاستلز ام الحواري بخرق أحد المبادئ التي صاغ تصور ها جر ايس، إما أن يكون الأسلوب "

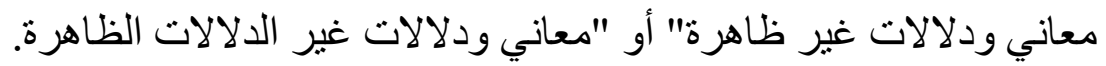

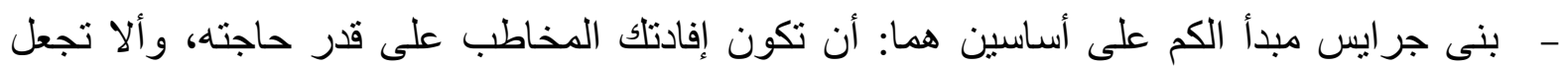
إفادتك تتعدى القدر المطلوب. ويسهر هذا المبدأ في ضبط التخاطب الصنا الصريح بين المتخاطبين، وفي حال خرقه ينبغي أن يصرف الكلام عن ظاهره، ويحتكم إلى القرائن التي تحدد المعنى المنصرف الفئ إليه.

- مقع في ثلاثية الحب لحسن البنداري خرق للمبادئ التي وضعها جر ايس، الأمر الذي أعطى النص

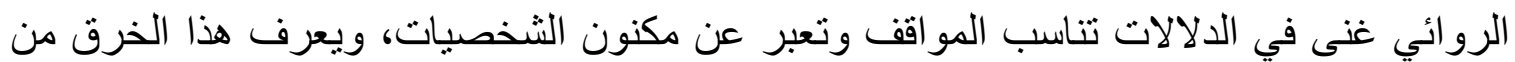
خلال استقر اء عناصر السياق الذي وقع فيه. الكلمات المفتاحية: الاستلز ام الحوار ـ الأديب حسن البنداري حياته و أعماله ـ ثلاثية الحب سب المقدمة

$$
\text { باحثة دكتوراه - كلية الاداب - كلية البنات - جامعة عين شمس }
$$

** أستاذ البلاغة والنقد الأدبي - قسم اللغة العربية وآدابها ـ كلية الآداب - جامعة عين شمس

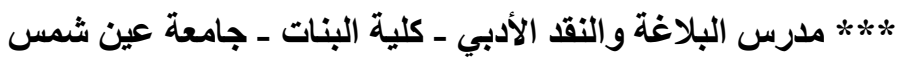




\section{العدد الثانى - الجزء الثانى (آ•「)}

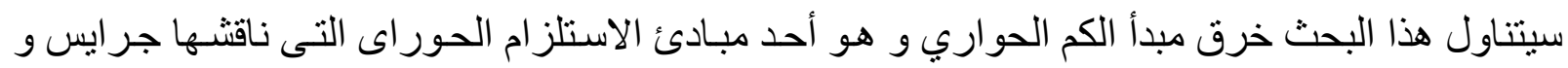

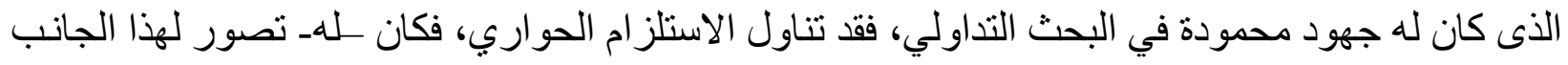

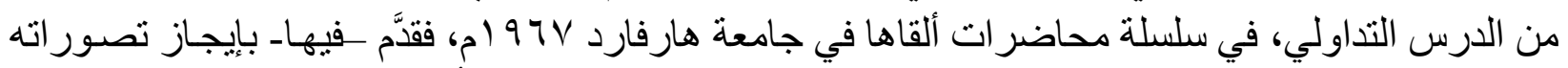

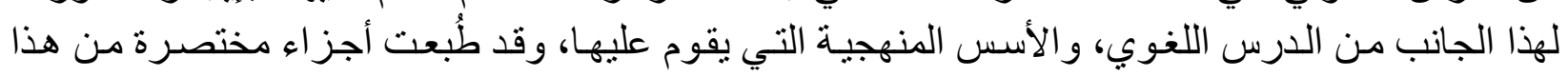

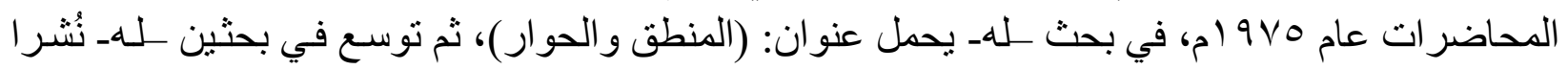

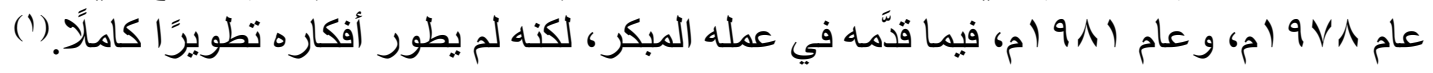
وضع (جر ايس) مبادئ خاصة للاستلز ام الحواري، هي:

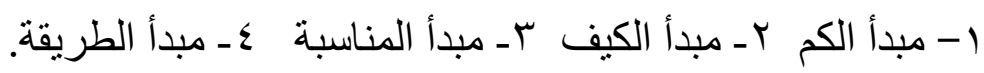

و هي المبادئ التي يتبين -من خلالها- مدى انحر اف المتكلم، و انتهاكه لقو اعد الخطاب، ممـا ينتج -عنـــ الاستلز ام الحواري.

ولما كانت تلك المبادئ تضبط التخاطب المثالي و الصريح بين المتحاورين؛ باعتبار هما ملتزمين -أبدًا ـ بمبدأ

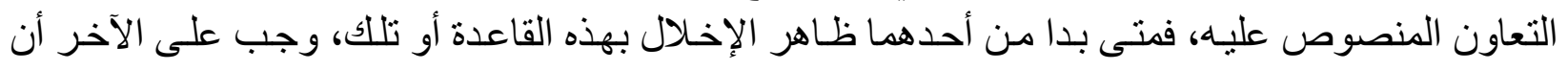

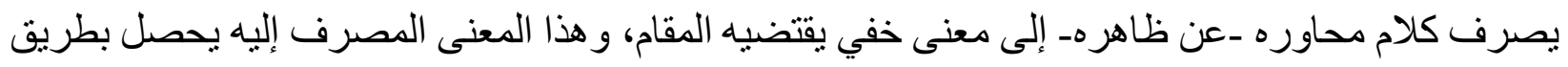

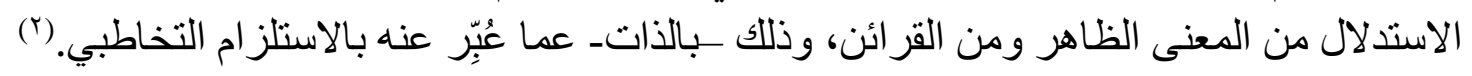
تعريف بالكاتب الأستاذ الدكتور حسن البندارى و أعماله:

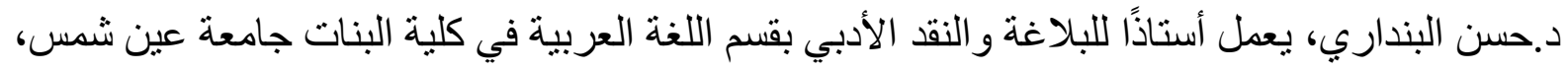

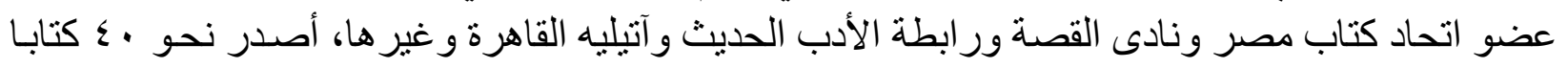

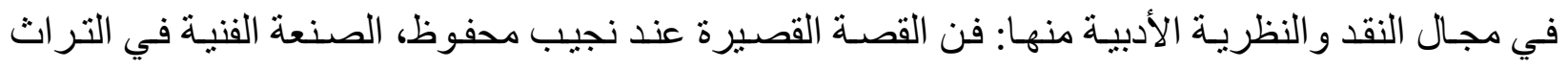

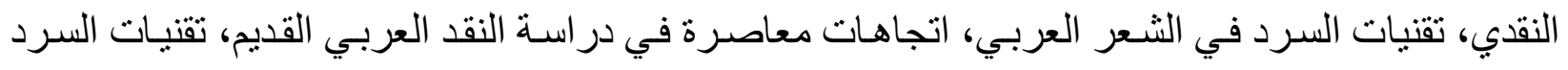
القصصي، رؤى نقدية في النص الإبداعي..

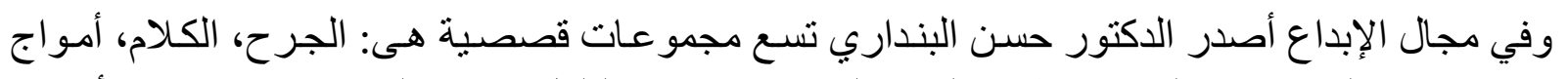

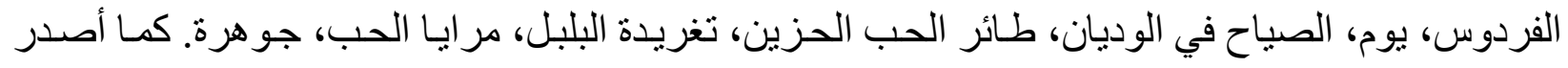

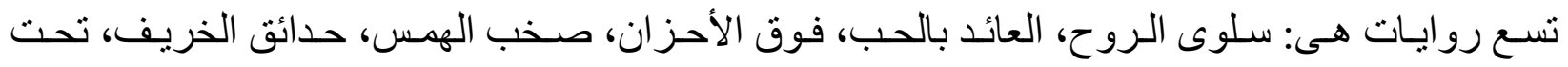

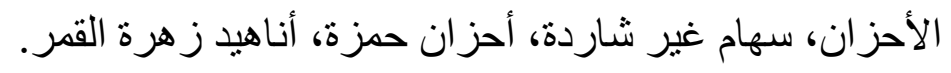

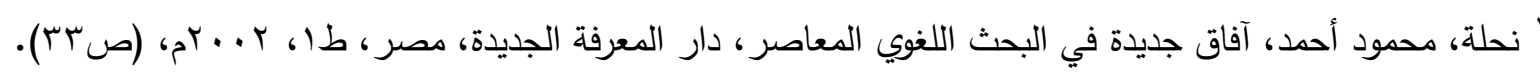

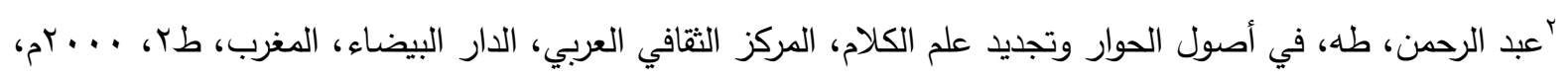
( ) (ص) 


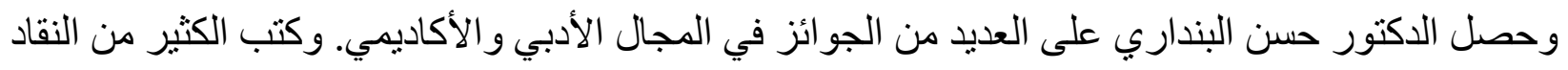

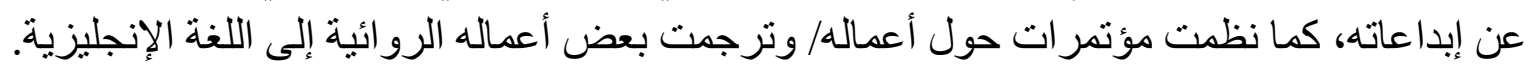

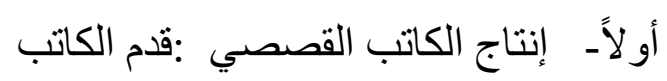
أ - - المجمو عات القصصية

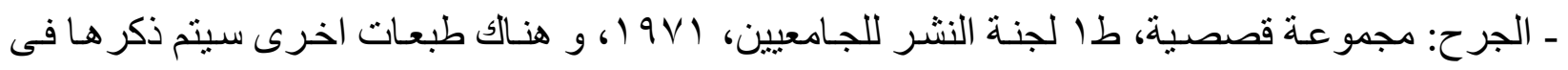

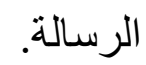

ـ الكلام: مجموعة قصصية، طا دار الفكر العربى، القاهرة، 1911.

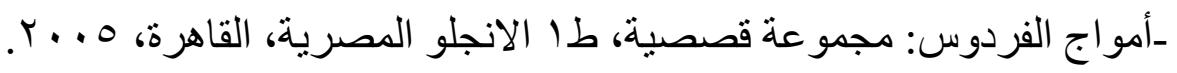

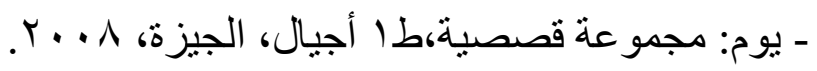

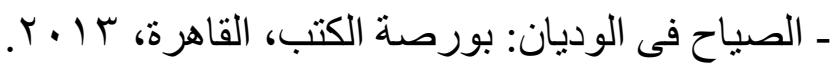
ـ طائر الحب الحزين: الانجلو المصرية، القاهرة، 10 ـ ؟؟.

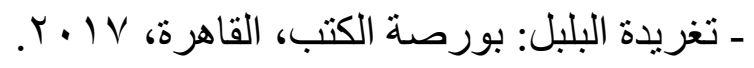
ـ مر ايا الحب: قصص قصيرة، مكتبة الانجلو المصرية، القاهرة، V V. Y. - جو هرة: قصص قصيرة، مكتبة الانجلو المصرية، القاهرة، VI ا ب.

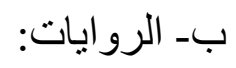
ـ سلوى الروح: ط1 مكتبة صقر، طنطا، ـ 197.

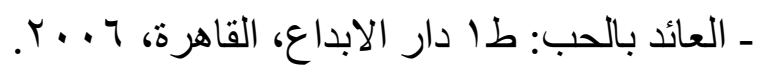

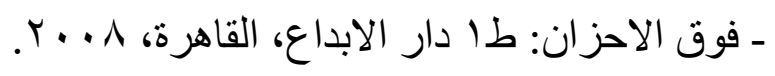
ـ صخب الهمس: طا دار الابداع، القاهرة، 9 . .. T.

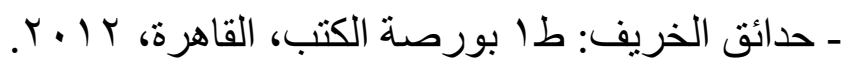

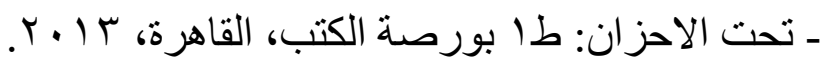

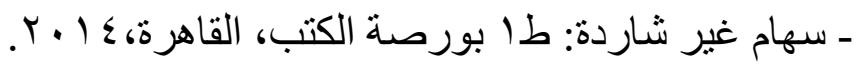
ـ أحزان حمزة: طا بورصة الكتب، القاهرة، 10 م ب.

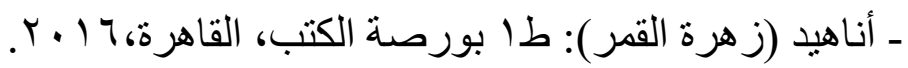

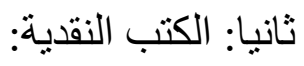




\section{العدد الثانى - الجزء الثانى (IГ•「) مجلة بحوث "اللغات لحوت "}

1 ـ فن القصة القصيرة عند نجيب محفوظ. طا مكتبة أم القرى، الكويت، ع19 أ.

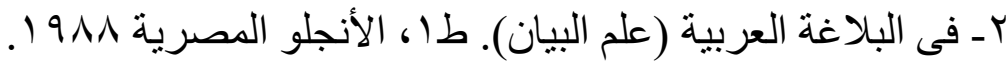

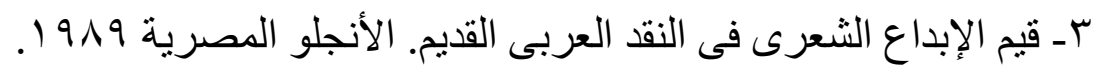

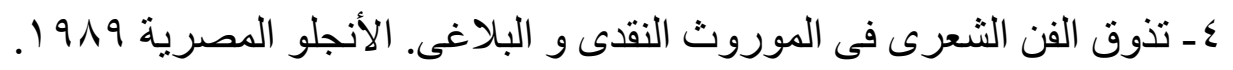

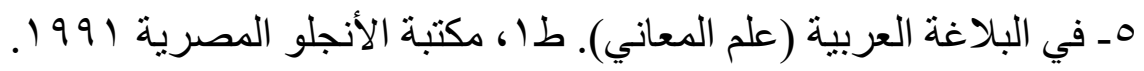

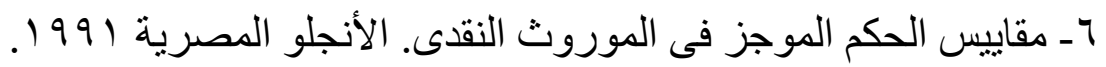

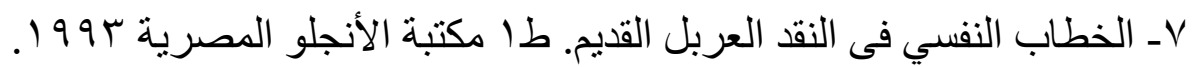
1ـ فاعلية التعاقب فى الثعر العربى الحديث. الأنجلو المصرية 990 أ. 9 ـ جدلية الأداء التبادلى فى الثعر العربي المعاصر. طا مكتبة الأنجلو المصرية، 990 (19.

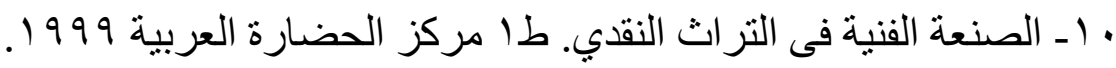
1) ـ طاقات الثعر في التراث النقدى. طا الانجلو المصرية 1999. r ا ـ إحكام النص الثعري فى الموروث النقدى و البلاغى. طا الأنجلو المصرية .... ب.

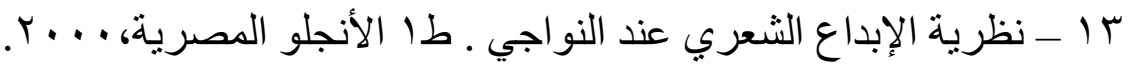

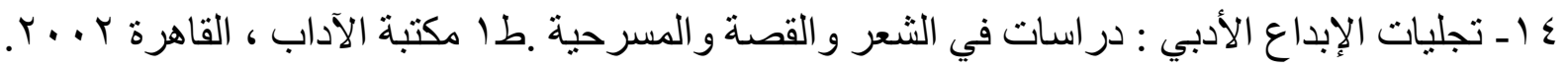

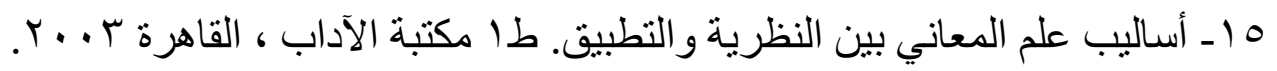
17 ـ الفنون البيانية و البديعية بين النظرية و التطبيق. طا مكتبة الآداب ، القاهرة ؟ . .؟.

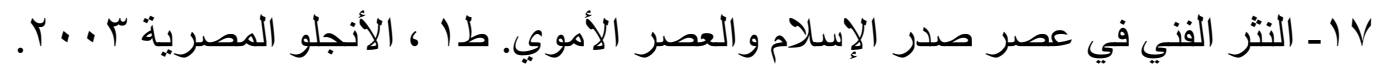

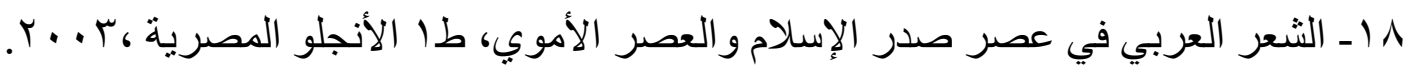

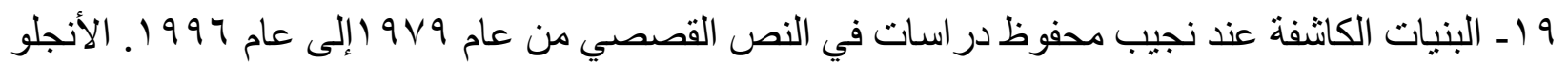

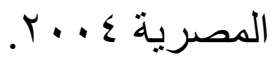

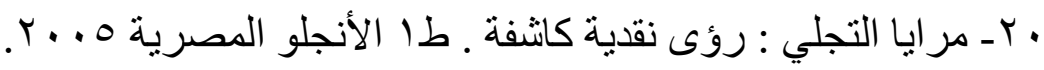

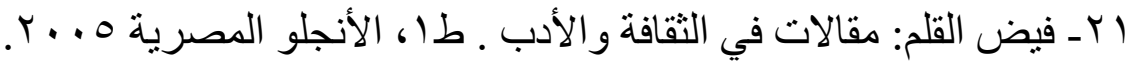

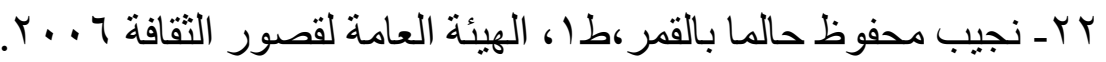

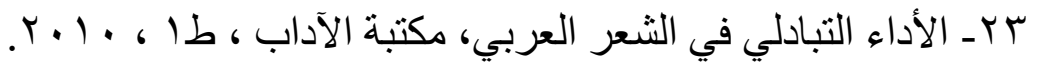

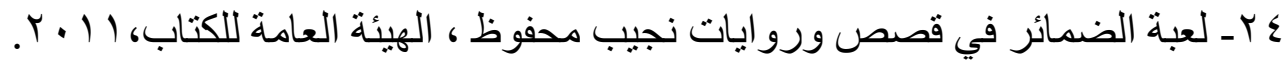




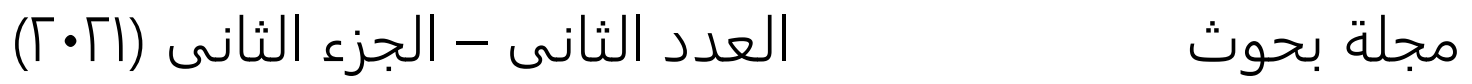 \\ "اللغات لهوت"}

هץ - تقنيات السرد في الثعر العربي: بورصة الكتب با • r.

بr ـ عمود الثتعر العربي بين الثبات و التحول في الموروث النقدي ( حتى نهاية القران الخامس الهجري) :

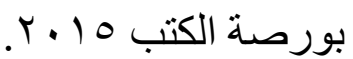

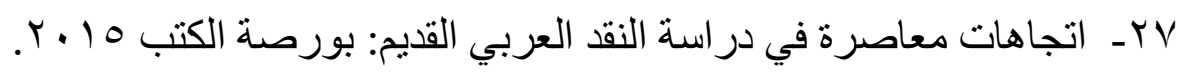

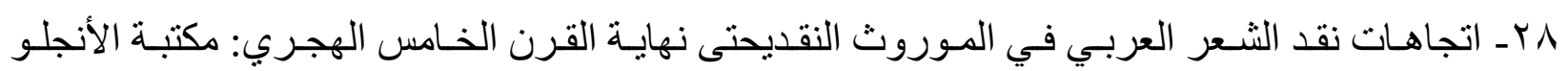

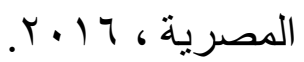

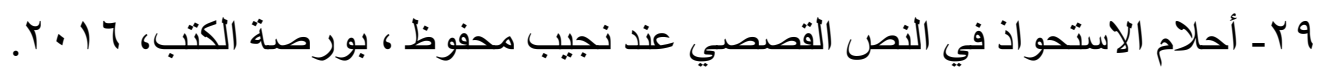

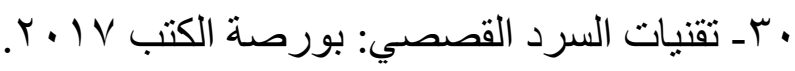

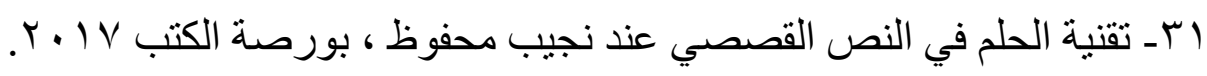

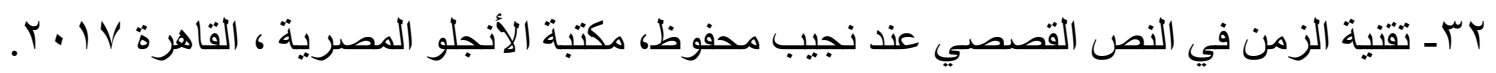

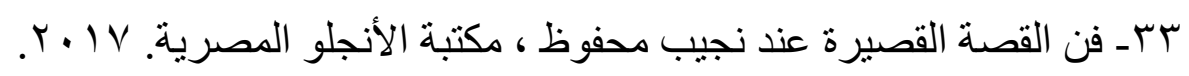

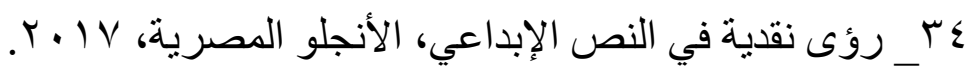

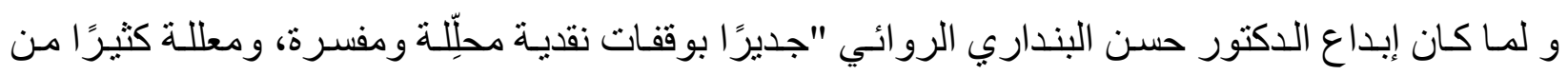

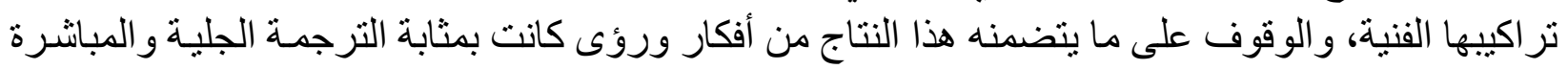

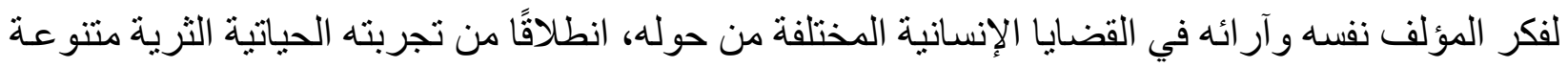

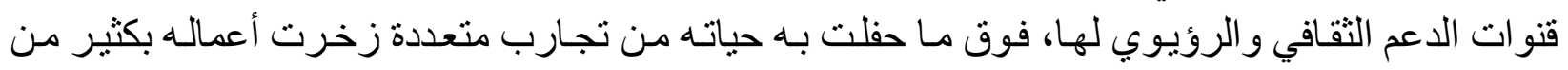

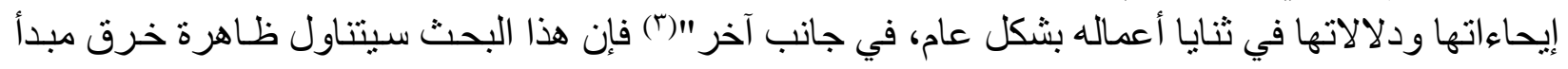

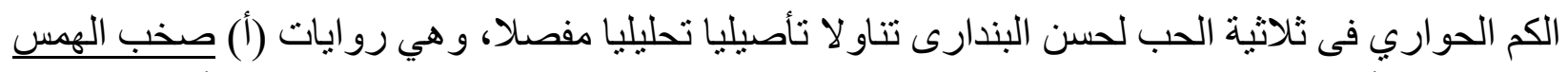

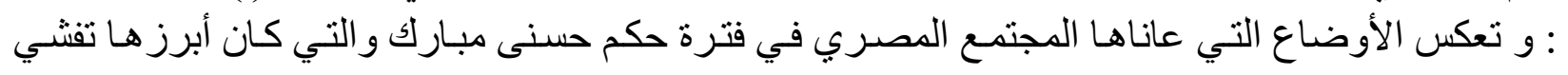

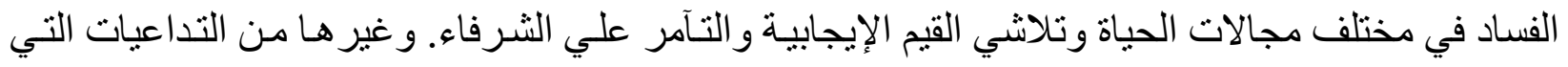
نتجت عنها ثورة مب منيناير.

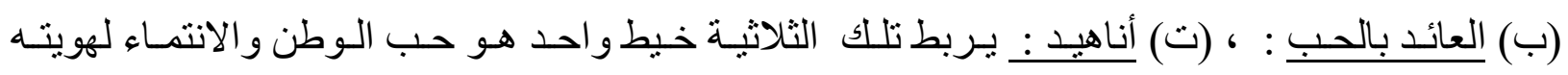

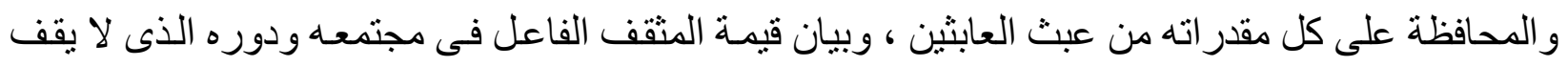

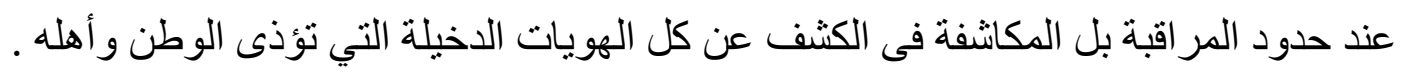

"نصر محمد عباس: الدلالات الرمزية وآفاق التوقع والانتظار في إبداعات حسن البنداري القصصية ـ رؤى نقدية، مكتبة

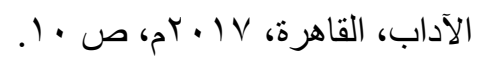

$-I M T-$ 


\section{العدد الثانى - الجزء الثانى (Iا•「) \\ مجلة بحوث \\ "اللغات بحوت"}

\section{خرق مبأ الكم في ثلاثية الحب}

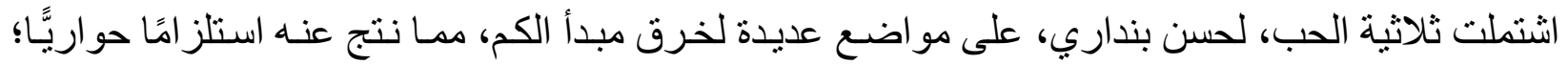
بإفادة معنى يخالف الدلالية الظاهرية للجملة من حيث الكم، حيث زادت الجملة الحوارية المقدَّرة طولاً بشكل واضح. وسوف نتناول تاليًَا مواضع خرق مبدأ الكم في الثثلاثية، وذلك على النحو الآتي: أولًا: رواية أناهيد

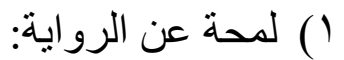

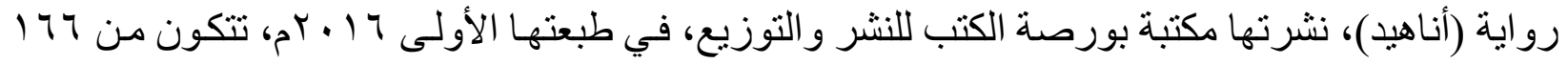

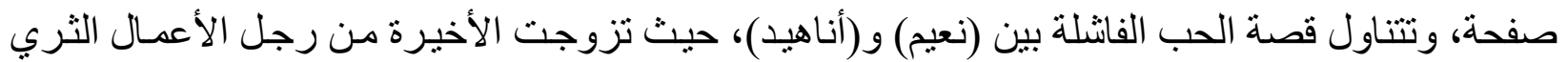

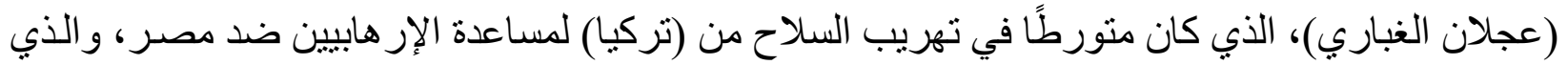

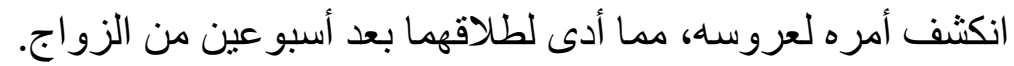

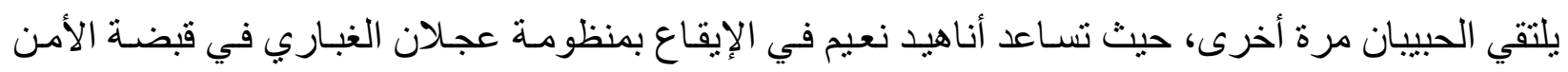

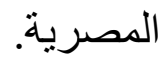

$$
\text { Y r مو اضع خرق مبدأ الكم في رواية (أناهيد): }
$$

وردت الكثير من الجمل الحوارية في سياقات مختلفة، توضح خروج دلالات الألفاظ عن ظاهر هـا إلى معانٍ مستلزمة أخرى مقصودة، ومن ذلكئ الكوارية السياق:

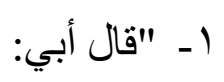

- - أنت الآن تجلس وحيدًا بلا أحد. لا زوجة ولا ولا.

سمعتني أهمس بصول خفيض: - - يا أبي، حضرتلك تعرف السبب. فأضافت أمي تخفف من وقع كلام أبي: - - ل يا نعيم، يجب أن تنسى.

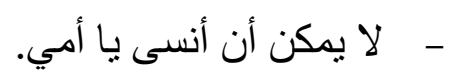
صار حتني بقسوة: - - هي الآن ملك رجل آخر. 


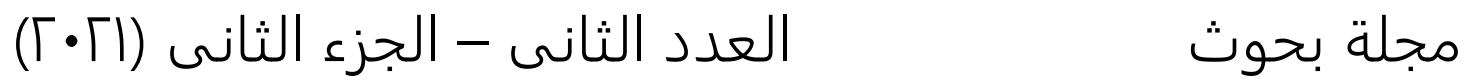 \\ "اللغات لهوت"}

$$
\text { فبادرت إلى القول: }
$$

- العريس ابن تاجر سلاح، و عليه تحفظات من السلطات، وجهات الأمن

- كلام غير مؤكد، ثم إن أسرتها و افقت. و هي موافقة. و لا حل. قضي الأمر. سافر بها إلى تركيا"(؛)

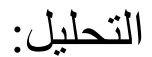

جاء خرق حكمة الكم في الحوار عندماز ادت الأم عن القدر المطلوب في إبداء رأيها في زوج (أناهيد)، من

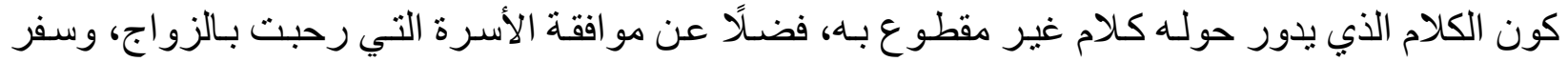

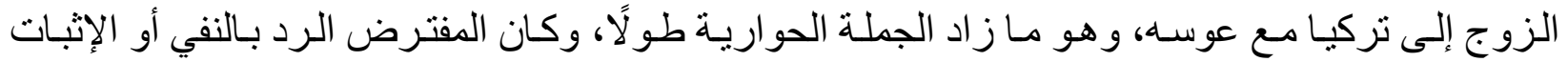

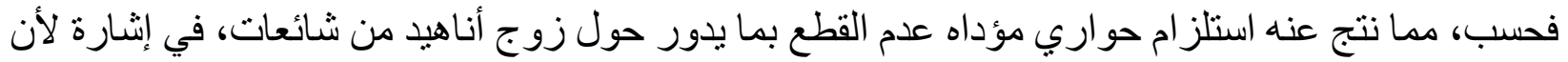
القضية لم تعد تخص ابنها (نعيم).

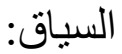

r- "وتساءلت: كيف يمكن أن أبقى مع المدير سحبان الجبالي الذي حاول بعد تعبيني بشهر أن

$$
\text { ير غمني على توقيع كثوف حسابات مزورة. }
$$

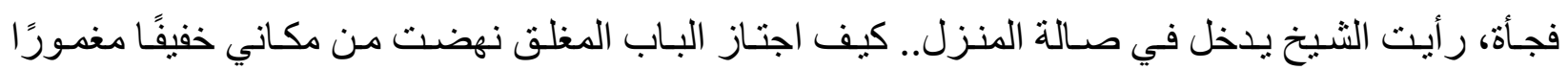

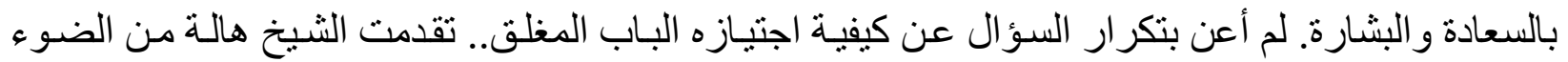

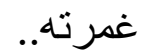
مد الثيخ يده اليمنى، ومسح جبهني، وقال:

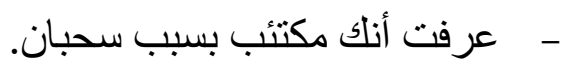
فأسر عت شاكيًا:

- ل المكن أن أغالط ضميري، وأوقع على كشوف تأكدت أنها مزورة" التحليل:

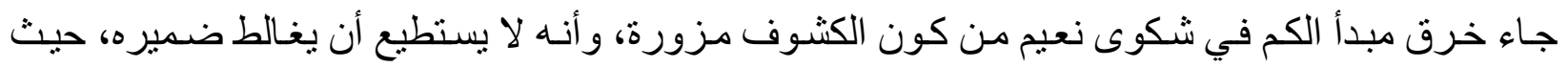

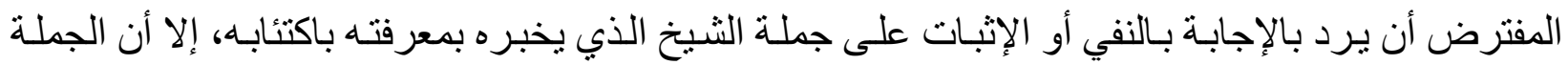

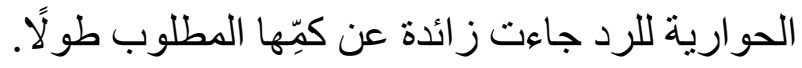

السياق:

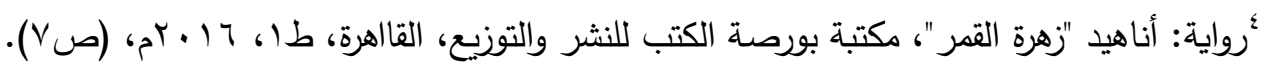




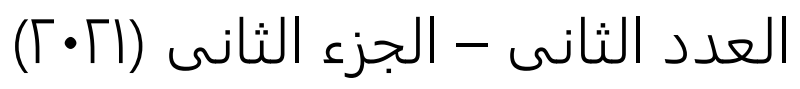

مجلة بحوث

"اللغات "

rــ "أنت في داخل نفسك تعلم أنها تستحق المواجهة، و المجابهة و الجهر بالمساندة.

فقلت ضائقًا:

- لاحظ أن عجزي عن اتخاذ قرار المجابهة سببه أسرتي.. أبي وأمي و إخوتي وأخواتي.

فأسر ع عثمان قائلًا:

- عرفت أن شقيقك منير تعاطف معك.

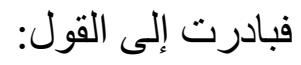

- - صوت منير لم يصدد طويلًا أمام الأغلبية الر افضة.

فقال عثمان مبديًا أسفه:

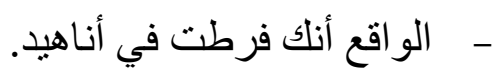

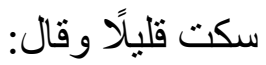

- على فكرة.. و الد أناهيد وو الدتها غادرا منزل الز هور إلى فيلا في الهرم بعد أيام قليلة من سفر أناهيد

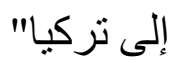

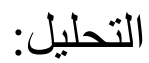

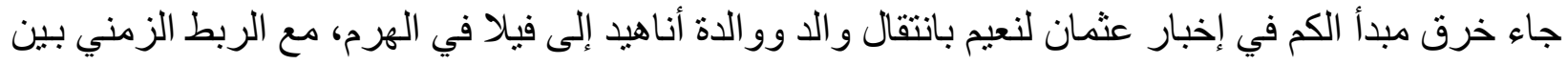

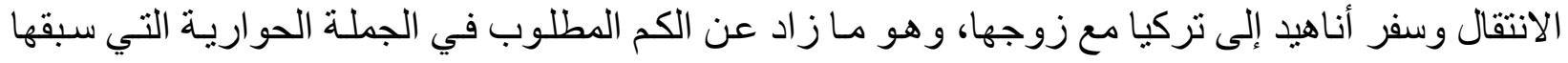

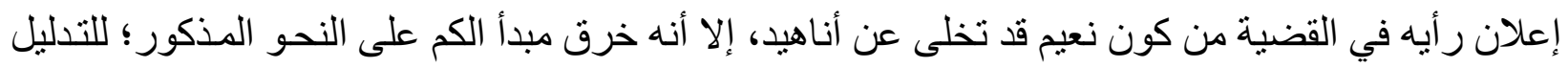

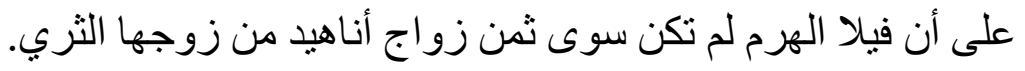
السياق:

ع - "أوصاني أبي وهو يحتضر منذ عامين حينما جئت إلى طنطا لزيارته في مستشفى الجامعة.

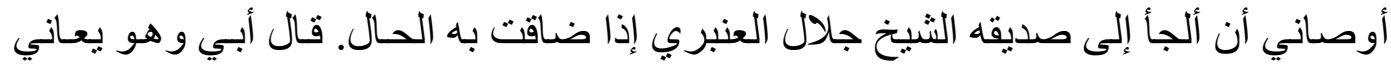

$$
\text { من آلام في صدره: }
$$

- كلم الثيخ جلال كلما ضاقت بك الحال.

$$
\text { ومرة سألت أبي: }
$$

- منذ منى تعرف الثيخ جلال؟

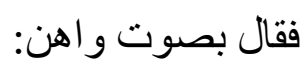




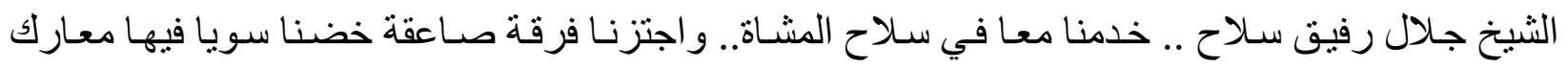

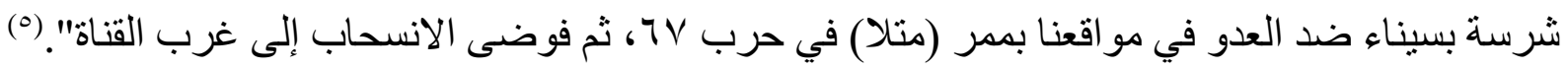
التحليل:

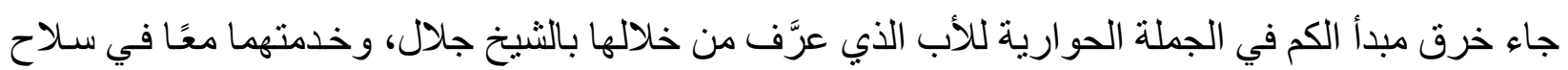

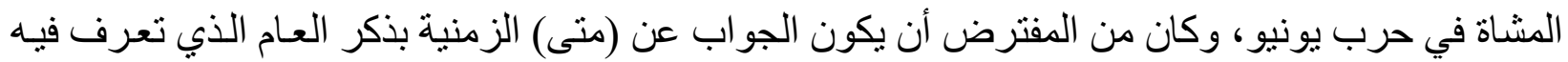

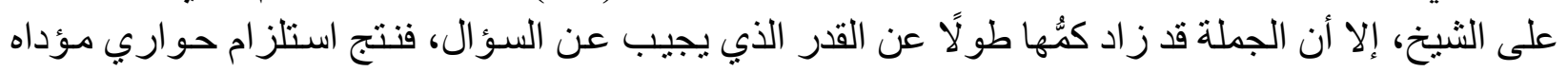
بيان طول فترة الصداقة بين الأب و الثيخ جلال النيل

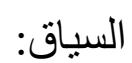

ــ " "هل أنا في خطر يا منصور؟

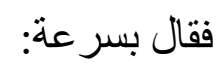

أكيد أنت في خطر با نعيم. فتساءلت:

وما العمل؟ وهل نجا سحبان من تدبير قتل عثمان؟ فقال: التحريات مستمرة حتى يتم الإيقاع به. عليك الآن أن تذهب إلى منزللك، وسوف أرسل خلفك من يحرسوك

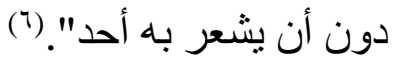
التحليل: - 20 - 20

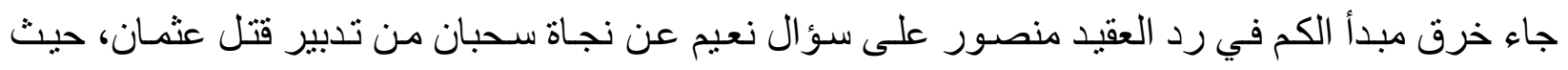

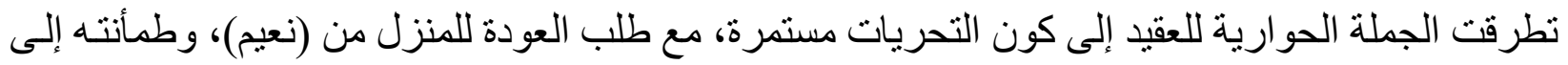

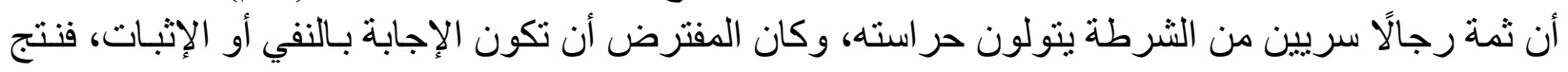

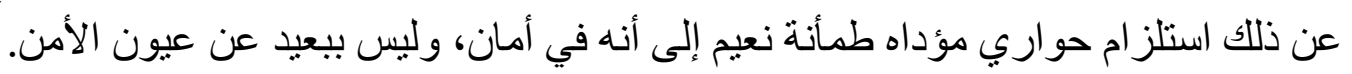

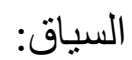

1 - "تقدمتني السكرتيرة الحسناء إلى الممر المؤدي إلى غرفة المحاسبات قبل أن تصل إلى الباب

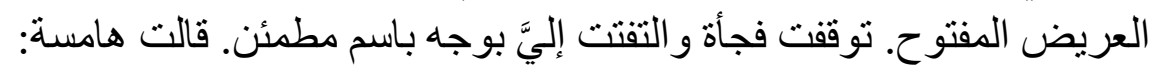

$$
\text { "أنا هيد، (ص آس). }
$$




$$
\begin{aligned}
& \text { - المهمة صعبة، ويجب أن أحذرك من البداية. } \\
& \text { فهمنْت: } \\
& \text { - من - }
\end{aligned}
$$

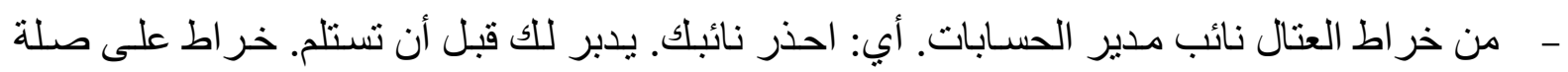

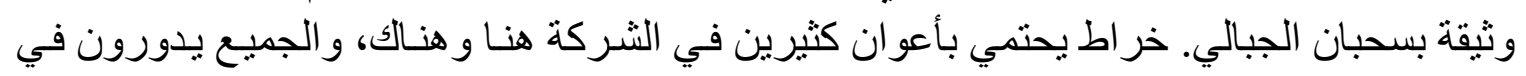

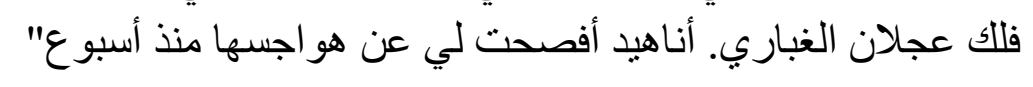

التحليل:

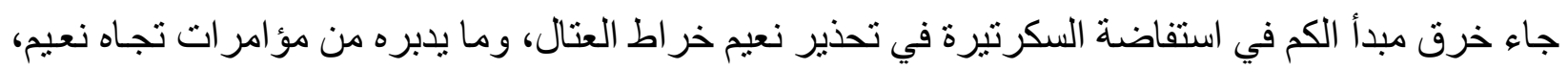

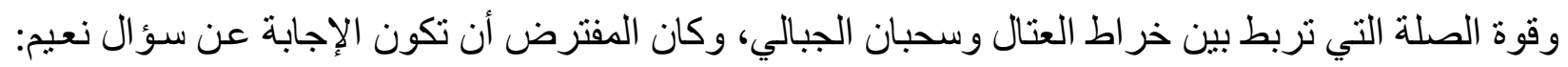

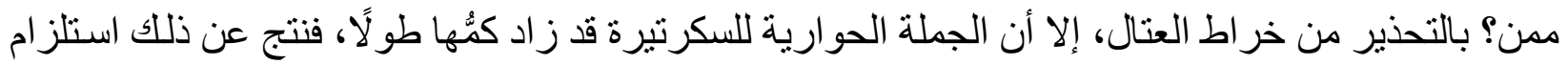

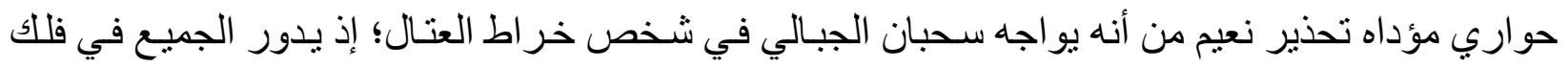

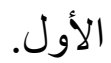

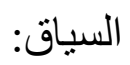

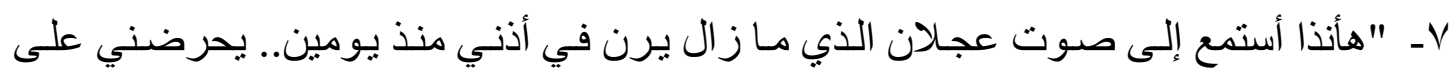

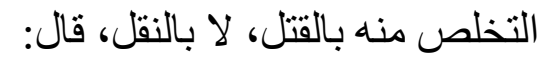
- - مبر لمصر عه لنستريح منه. فقلت: - - مضية اغتيال عثمان لم تغلق حتى الآن.

- - سأساعدك و أوفر للك من يقوم بالمهمة. المهم أن تو افيني بأخبار تحركه من الصباح حتى العودة إلى

$$
\text { منزله في المساء" }
$$

التحليل:

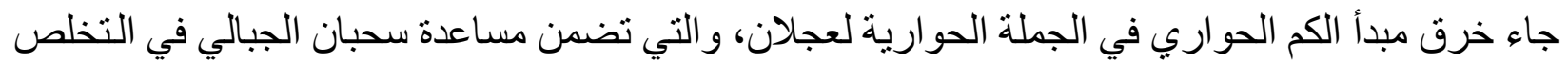

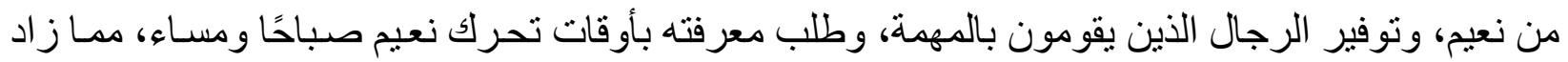

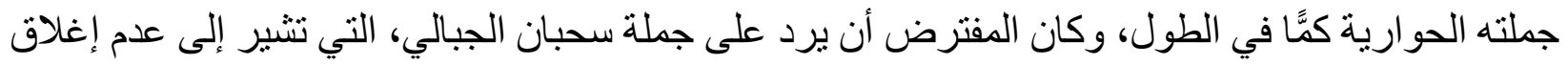

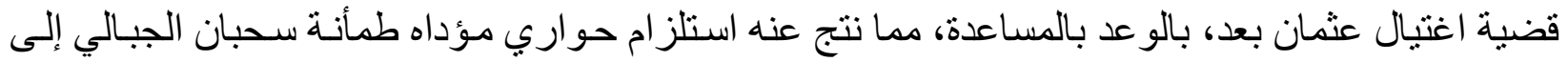

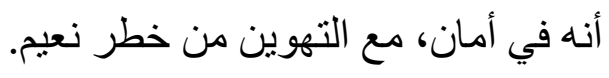




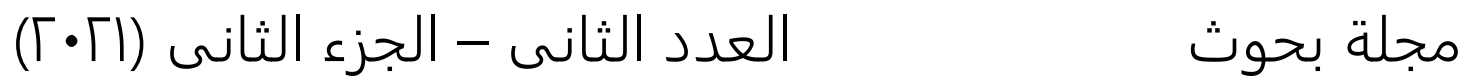 \\ "اللغات لهوت"}

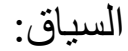

A- "حضرتلك أناهيد الصافي؟

$$
\begin{aligned}
& \text { فأسر عت في الإجابة: } \\
& \text { نعم، أنا أناهيد الصافي. } \\
& \text { فعقَّب قائلًا: }
\end{aligned}
$$

حضرتلك مطلوبة في قسم شرطة الطالبية لإجر اء تحقيق.

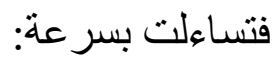

عن أي شيء؟

فقال:

عن ملتَّمين حساولوا الاقتر اب مـن الفيلا منذ سـاعة.. تم إلقاء القبض عليهمـا. أبلغنـا شخص لم يفصـح عن

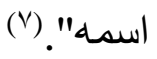

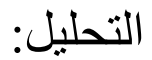

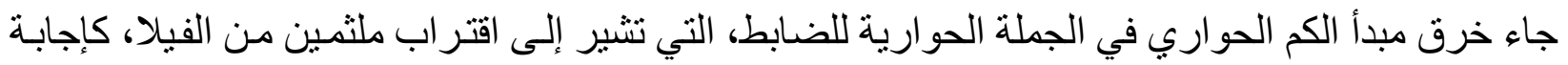

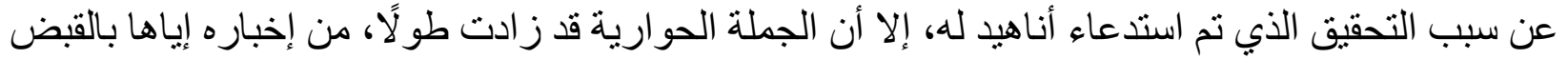

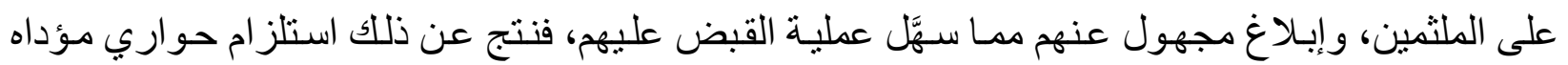

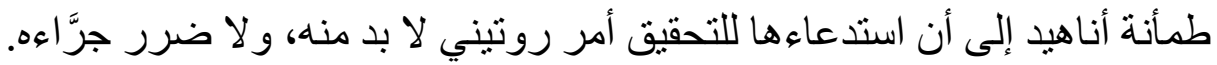
ثانيًا: رواية (العائد بالحب)

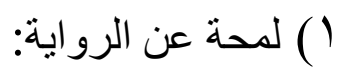

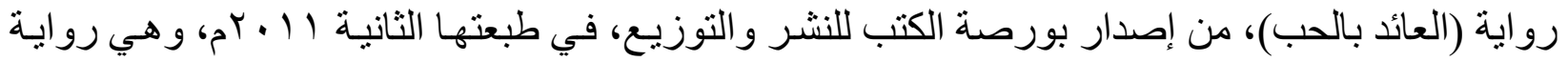

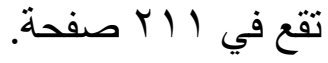

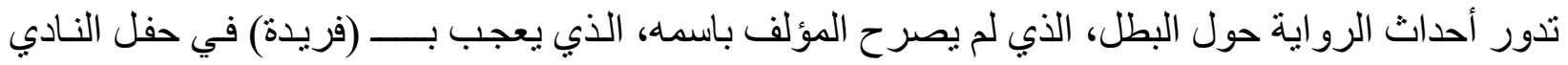

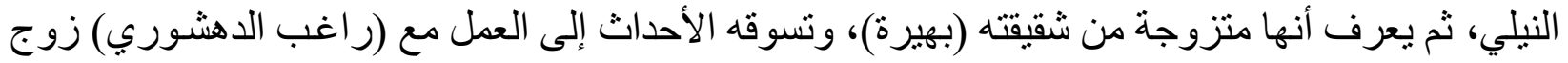

فريدة، و الذي يتورط في قتل (رشدي) زوج بهيرة. يتعرف البطل على (سعفان الغانم) الذي يساعده في الإيقاع بر اغب الدهشوري، بمساعدة سكرتيرته. 


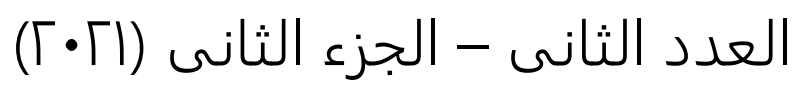

مجلة بحوث

"اللغات " ل

$$
\text { r }
$$

وردت الكثير من الجمل الحوارية في سياقات مختلفة، توضح خروج دلالات الألفاظ عن ظاهر هـا إلى معانٍ مستلزمة أخرى مقصودة، ومن ذلك:

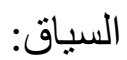

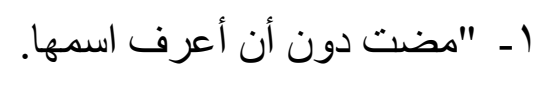

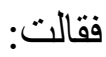

فريدة البدري.. اسمها فريدة البدري.. زميلة الدراسة وجارتنا بعابدين. ألا تذكر ها؟ همستُ بو هن: مضت ثلاثون عامًا.. شعرت طو ال الوقت أنني رأيتها من قبل. زوجها راغب الدهشوري

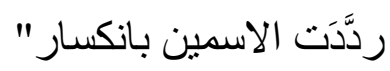
التحليل:

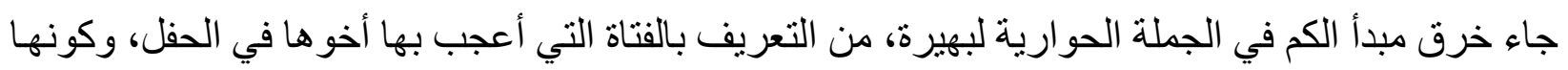

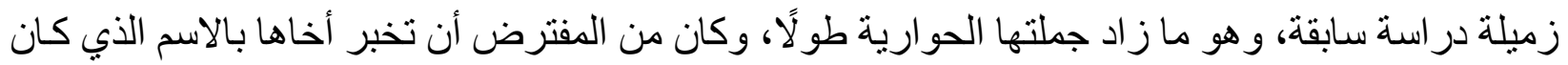

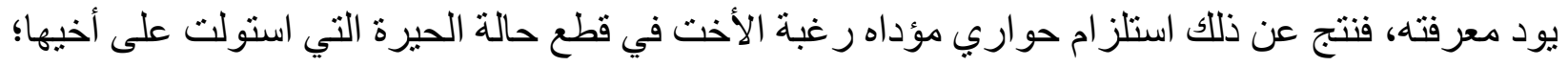
بإفادته بجميع ما تعرفه عن الفتاة التي أعجبته.

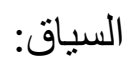

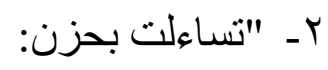

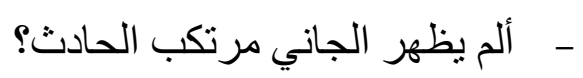

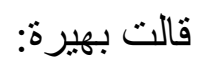

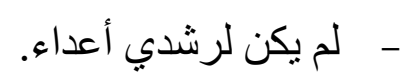

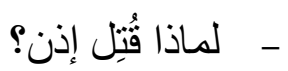
- كل ما فعله أن شركته التي أسسها، بعد عودتنـا بخمس سنوات، كانت تزدهر عامًَا بعد آخر، عددَّه

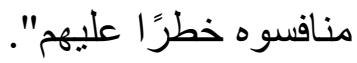


جاء خرق مبدأ الكم في الجملة الحوارية لبهيرة، التي أرجعت سبب قتل زوجها لتشكيله خطرًا على المنافسين،

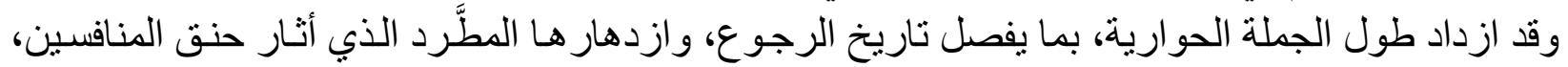

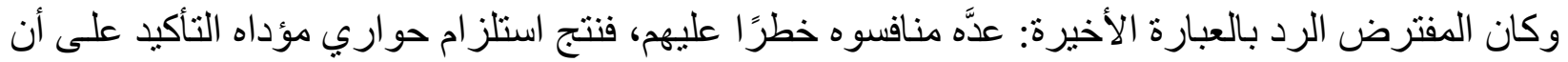

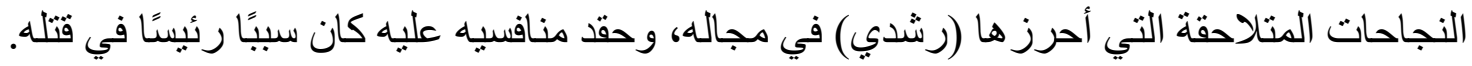

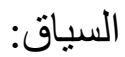

rــ "لايَّ معلومات تجعلك تفكر مرتين قبل أي اتفاق خاص بمشرو عك.

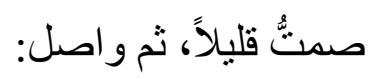

- - م المعلومات التي لايَّ أكيدة وموثوقة.

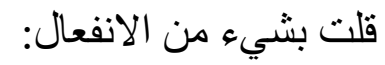

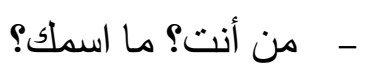

- - - أنا سعفان الغانم سكرتير زاهد العابد.

فقلت بفضول شديد تمازجه سخرية:

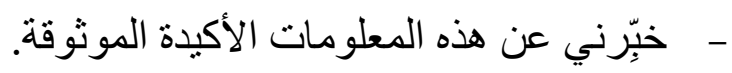

- ل - لن أتحدث في التليفون عن أي شيء.. الأفضل أن نلتقي.

- أنتظرك في الثامنة و النصف.. لكن كيف عرفت رقم التليفون.

فقاطعني قائلًا:

- و أعرف ايضًا مسكنك. لا يخفى عليَّ شيء. الأفضل أن نلتقي".

التحليل:

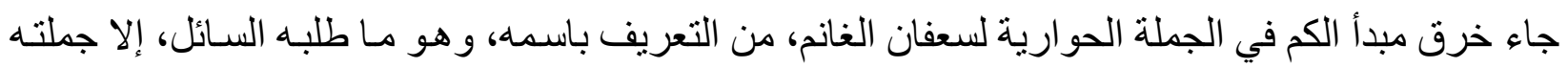

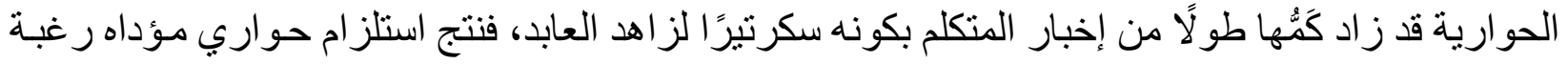

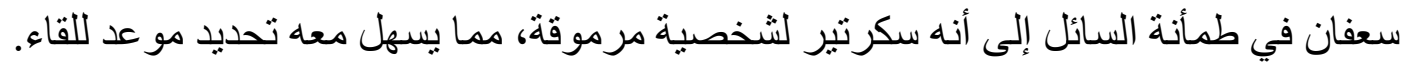
السياق:

ع - "- أنا السكرتير الثالث لز اهد العابد.

توقف قليلًا ثم قال: 


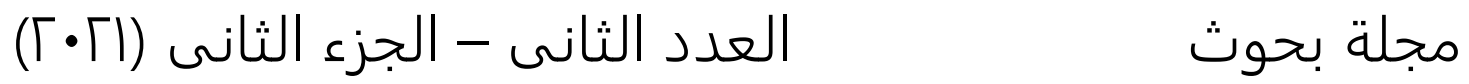 \\ "اللغات لهوت"}

- - معلوماتي أنه يدبر مع آخرين لإضرارك. فسألته بريق جاف:

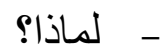

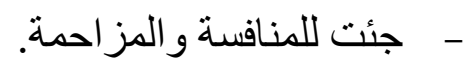

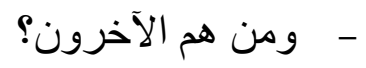
- - - مض من قابلتهم أمس في النادي. قلت أستدرجه:

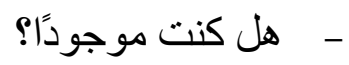
- نعم، و استمعت لمحاضرتلك القيّمة. و أعجبت بأفكارك. و هذا مـا دعاني اليوم لتحذيرك؛ و لأكون في خدمناك ور هن أنشارتلك". (^)

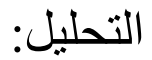

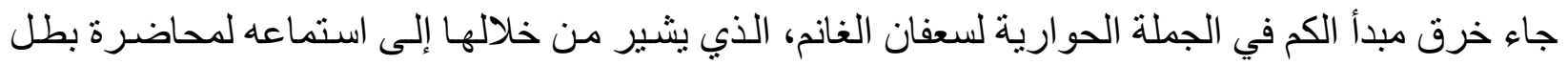

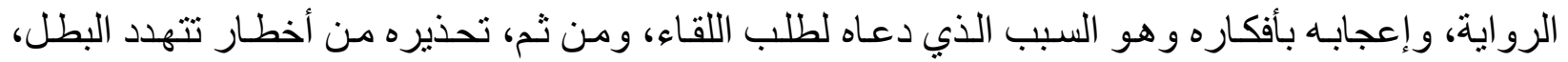

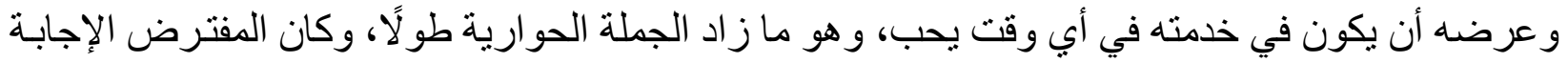
بالنفي أو الإثبات، مما نتج معه استلز ام حواري مؤداه تقرير الأرضية المشتركة التي تجمع بين الطرفين، بما لإنا

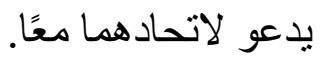
السياق:

$$
\begin{aligned}
& \text { 0ـ "فقال بثقة كبيرة: } \\
& \text { - لي مصادري.. أعرف كل شيء يجري في البلد. } \\
& \text { فقلت مختبرًا تقته الكبيرة: } \\
& \text { - فهل عرفتَ بمو عدي صباح اليوم؟ - فئم } \\
& \text { - - نعم. و أبارك تكوين شركتكم الجديدة" }
\end{aligned}
$$

^رواية: العائد بالحب، مكتبة بورصة الكتب للنشر والتوزيع، القاهرة، طس، 10 • بrم، (صr؟). 


$$
\text { "اللغات بحوث " }
$$

التحليل:

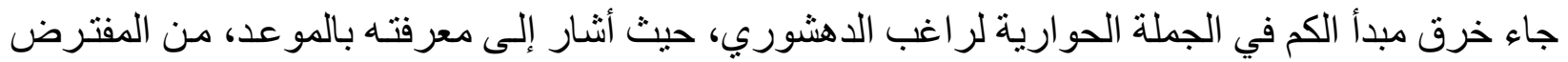

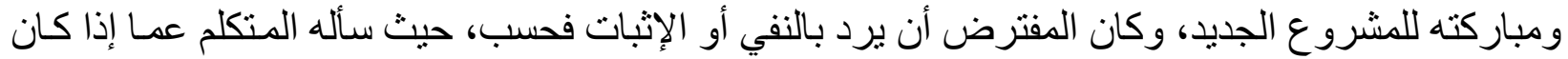

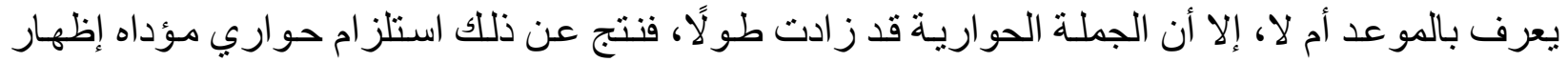

راغب الدهوري نفسه بمظهر الرجل ذي المصادر المتعددة، والذي لا يخفى عليه صغيرة أو كبيرة. السياق:

T- "- إنه عائد الآن في الطريق الصحر اوي.. تصرف بسرعة.

توقفت الأصوات تمامًا.. ثم سمعت صوت حازم السو احلي يقول:

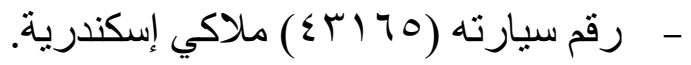

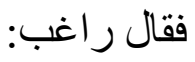

$$
\text { - - مل تأكدت أنه هو }
$$

- - تم المطلوب قبل العامرية. وقد أرسلنا من تأكد من مصر عهة

التحليل:

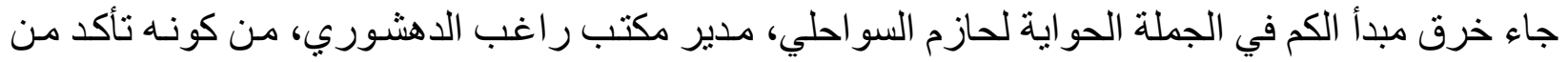

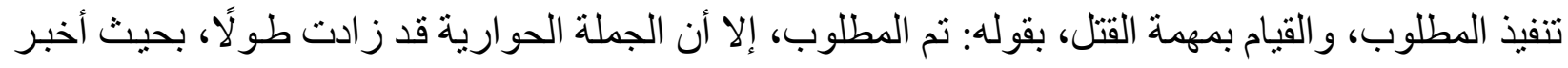

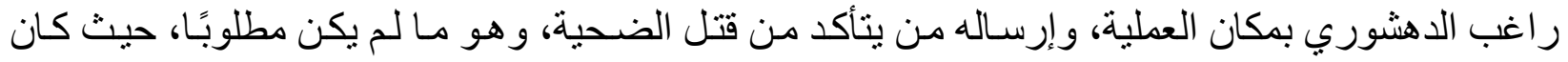
يفترض الإجابة بالنفي أو الإثبات، فنتج عن ذلك استلز ام حواري مؤداه التأكيد على تنفيذ المهمة، بمـا بطهئن

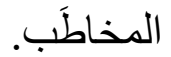

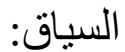

ل - " - راغب الدهوري خلف مصر عزوجي رشدي.

$$
\text { - }
$$

- إثر اق سكرتيرته دلتني على قاتله المحترف.. كدنا نصل إليه لو لا أنه مـات مسمومًا عقب تتناول

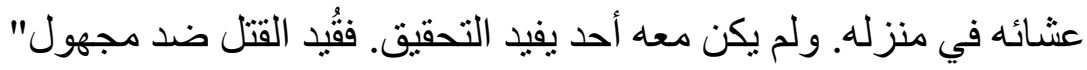

التحليل: - n

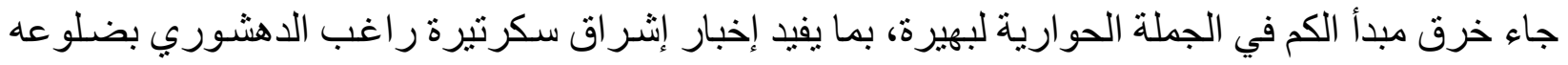

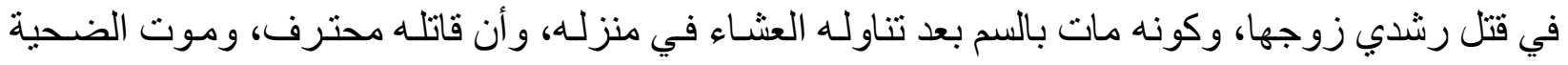




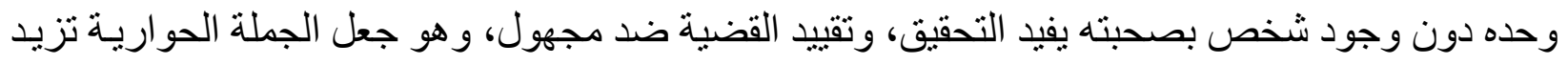

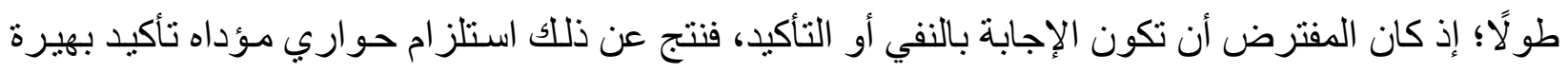
على تورط راغب الدهشوري في قتل زوجها. السياق:

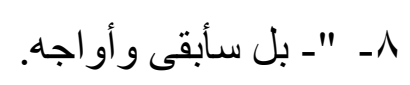

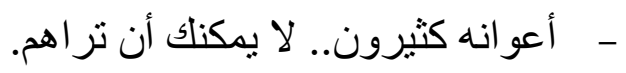

$$
\begin{aligned}
& \text { - لابد من المواجهة. } \\
& \text { - ليس معلك أحد. }
\end{aligned}
$$

- - معي الله.. ألا يكفي أن يكون الله معي"

التحليل:

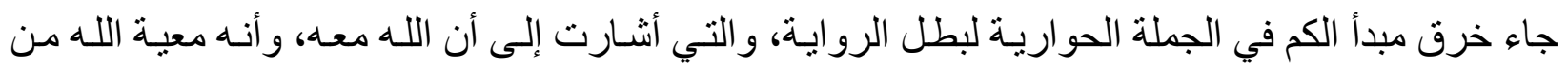

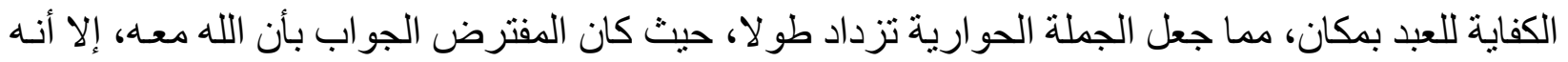

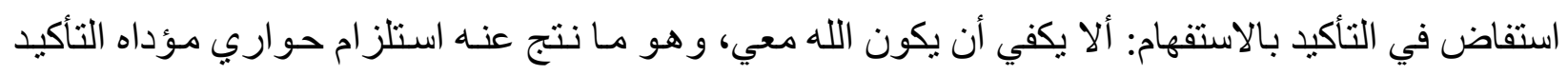
على كفاية الله للمخلصين الثرفاء.

9- "ربتت ظهري بحنان شقيقتي بهيرة التي قالت وهي تنظر إليّ: - طول مدة إقامتك بالمستثفى كان دائمًا اثنان منهم يقفان أمام الباب بالتناوب.

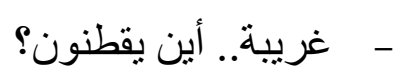

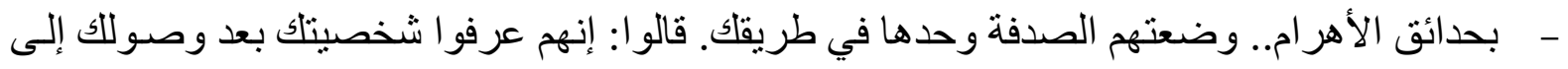

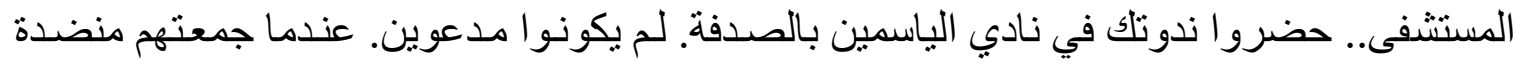

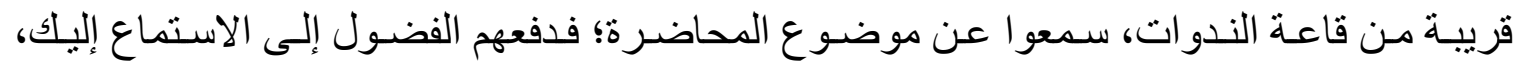

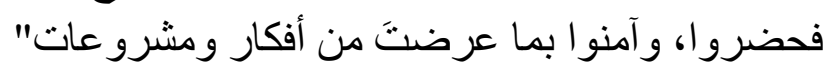

التحليل: - 20 - n

جاء خرق مبدأ الكم في رد بهيرة على سؤ ال أخيها عن المكان الذي يسكن فيـه المعجبون الذين الذين حضروا

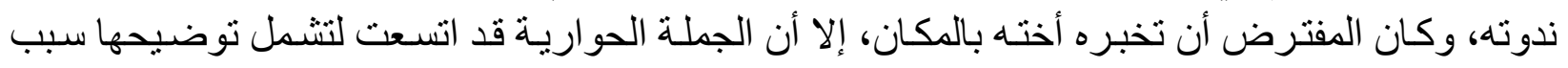

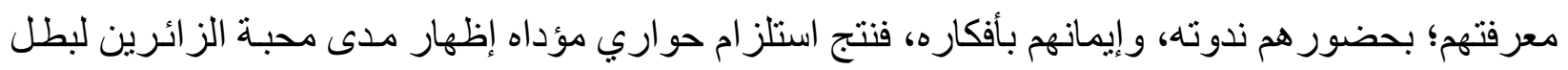




$$
\text { "اللغات بحوث " }
$$

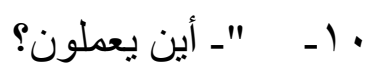

- - إنهم مهندسون حديثو التخرج، ويعملون في مو اقع مختلفة كما قالو ا.

$$
\text { - - - - أحب أن أنعرف إليهم. - }
$$

التحليل:

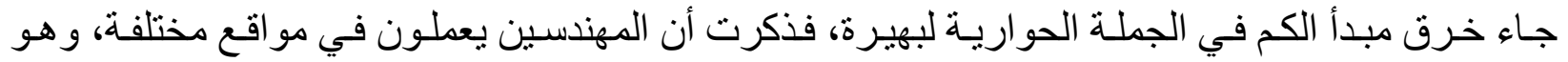

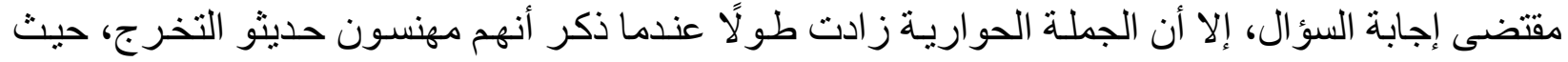

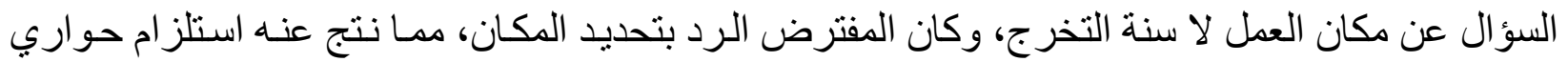

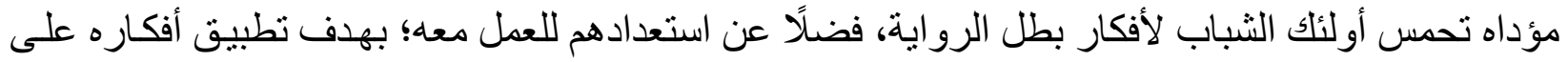

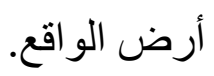

$$
\text { ( ) لثالثًا: رواية (صخب الهمس) عن الرواية }
$$

رواية (صخب الهمس)، من إصدار مكتبة البورصة للنشر والتوزيع، في طبعتها الثانية | (ا ـ بم، وهي روايـة

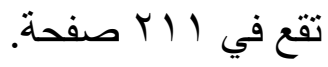

تدور الرواية حول البطل الذي لم يصرح المؤلف باسمه و أخيه (صفوان) الذي يُعنسى بمتابعة الممارسـات الإسر ائيلية، وخططها التآمرية ضد الدول العربية، وخصوصيًا مصر ؛ باعتبار ها دولة رائدة في المنطقة. يختفي صفوان في ظروف غامضة، وبعد عدة تهديدات بالقتل، يظهر الإرهابي (مانويل زخاري) الذي تحوم شبهات حوله في اختطاف (صفوان)، وضلو عه في تصفية عدة شخصيات، وتستمر جهود البحث عن صفوان حتى نهاية الرواية.

$$
\text { r ) مو اضع خرق مبدأ الكم في رواية (صخب الهمس): }
$$

وردت الكثير من الجمل الحوارية في سياقات مختلفة، توضح خروج دلالات الألفاظ عن ظاهر هـا إلى معانٍ مستلزمة أخرى مقصودة، ومن ذلك:

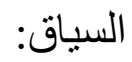
1- "- أمنتا القومي يفرض علينا التدخل. 


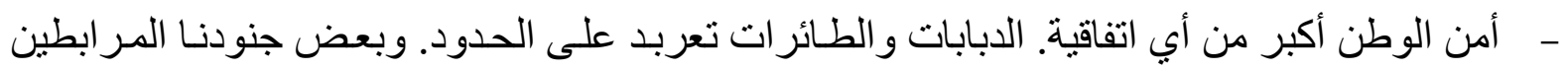

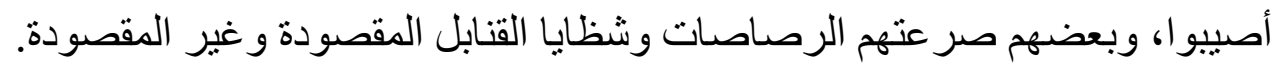

$$
\begin{aligned}
& \text { - الأمل كبير في وقف الحرب.. الدول تتحرك بسر عة. } \\
& \text { - ـ لن تتوقف الحرب إلا بعد الانتهاء من المهمة.. } \\
& \text { - - }
\end{aligned}
$$

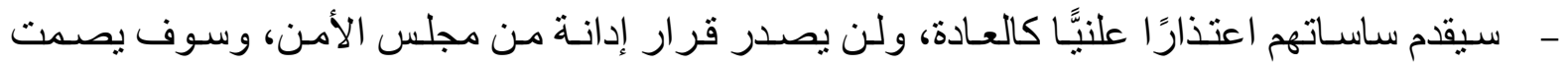

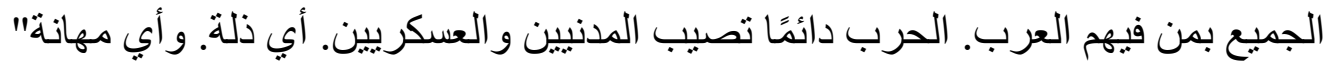

التحليل:

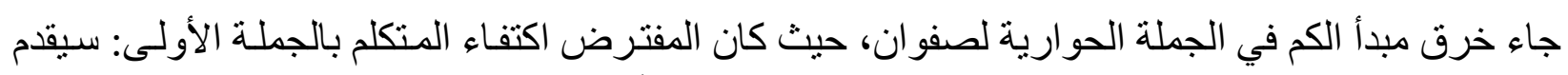

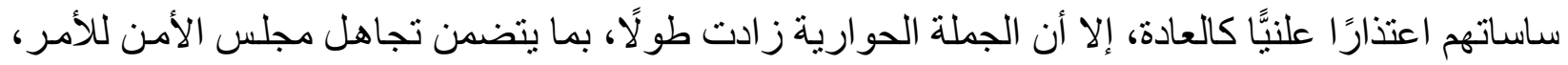

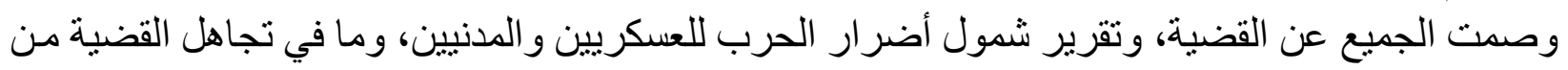

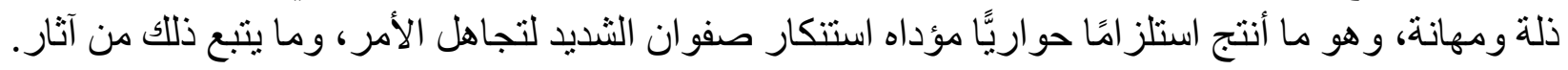
السياق:

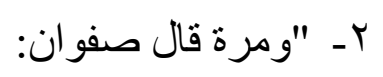

- أعلم أن المخابرات المعادية تجند عملاء من بين مواطني الوطن.

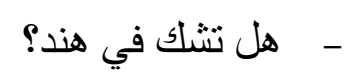

- أنا لا أتهم.. ولكن الاحتمال قائم. خاصة أن ابن شقيقتنا مجدي تحدث إلـيَّ فيما تحدث إليك: (مر اقبـة

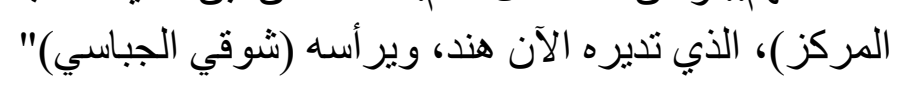

التحليل:

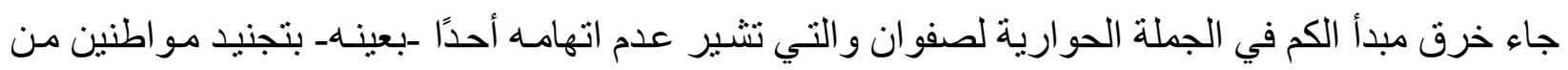

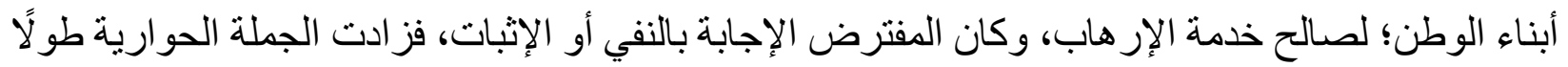

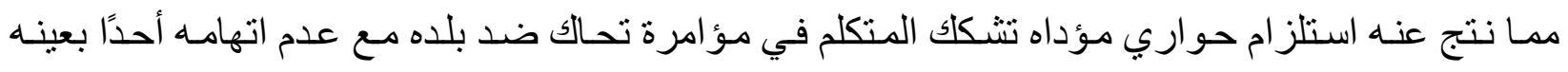
بالتورط فيها. السياق:

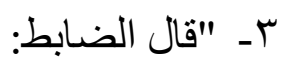
- - منى رأيت صفوان آخر مرة؟ - مبط 


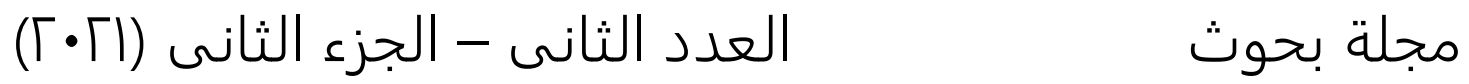 \\ "اللغات لهوت"}

- - مس عندما وصل في الساعة الخامسة.

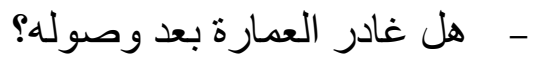

У -

- - مل تركت باب العمارة بعد الخامسة؟

- - مأنا لا أترك باب العمارة أبدًا إلا للحمَّام"

التحليل:

جاء خرق مبدأ الكم في الجملة الحوارية لحارس العقار ، حيث كان المفترض أن برد بـالنفي و الإثبات، إلا أن

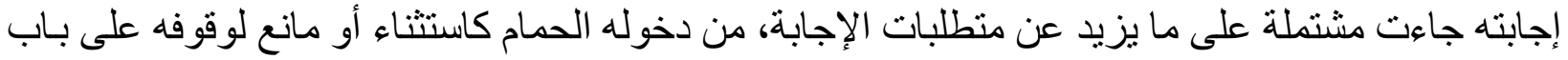

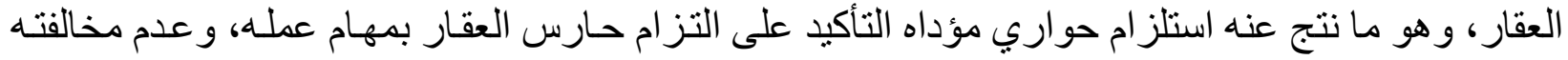

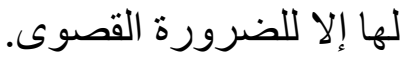

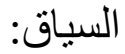

عـ "- دكتور نبيل.. هل يسمح وقتلك وعملك بما تقوم به؟

- - أوفق بين عملي و التحري حتى أصل إلى الحقيقة.

- - ـ أيمكن أن يكون أمين الثرطة وراء اختفاء خالد صفو ان التي سلمتها للضـابط هشام؟

- لا تستبعد أي شيء. إنه ضالع ونحن لم نسترح إليه حين رأيناه أول مرة"

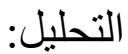

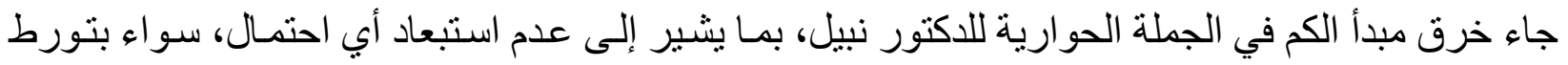

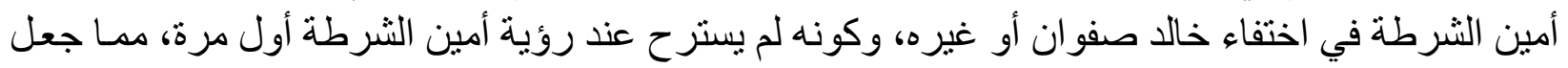

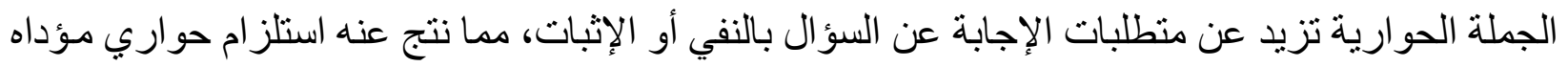
عدم اتهام أحد بعينه، مع مو افقة السائل في عدم استبعاد أمين الثرابة الثرطة.

0ـ "بمجرد أن دخلت بادرني رئيس النيابة ماهر الغمر اوي بقوله:

- تحرياتنا اتسعت وزادت. تجاوزت الجيزة و القاهرة.

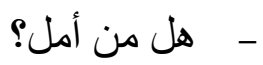

- شملت التحريات جميع معارف صفوان الكاثف، و أقاربه و أصدقاءه، وزملاءه في الجريدة، وسكان

العمارة، و المحال المجاورة، ووضعت بعض التعان التليفونات تحت المر اقبة" 
التحليل:

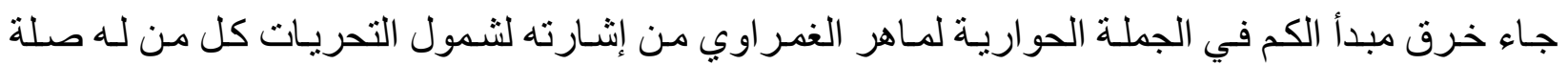

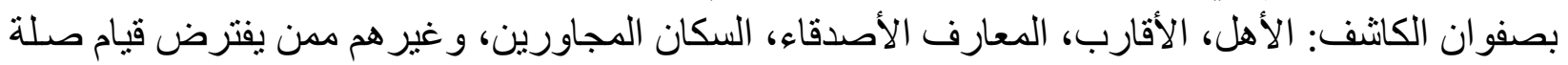

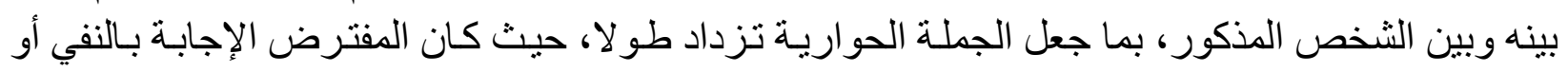

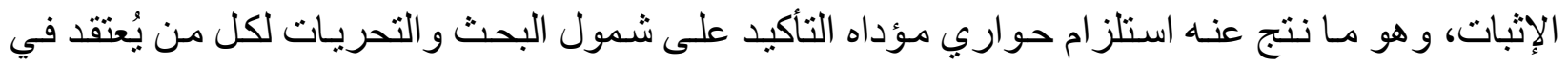
صلتهم بصفوان الكاشف. وهن مانج السياق:

T- "ـ أجد دائمًا شخصًا في المصعد يتغير كل يوم.. أنشعر أنني مر اقب.

$$
\begin{aligned}
& \text { - منذ متى؟ - } \\
& \text { - - من أول أمس. }
\end{aligned}
$$

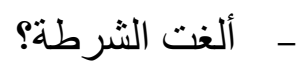

- - بماذا أبلغ؟ لم يتعرض لـ لي أحد حتى الآن. فقط أر اني تحت المر اقبة"

التحليل:

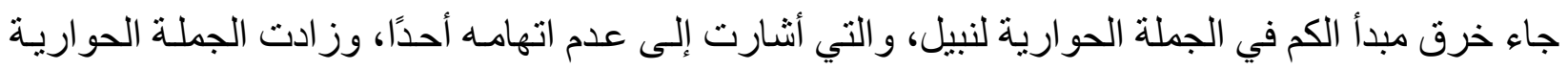

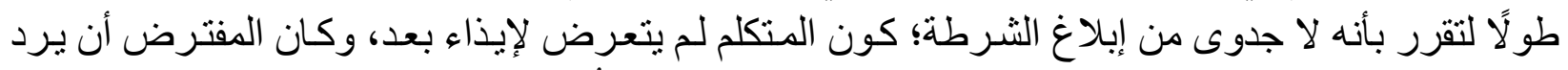

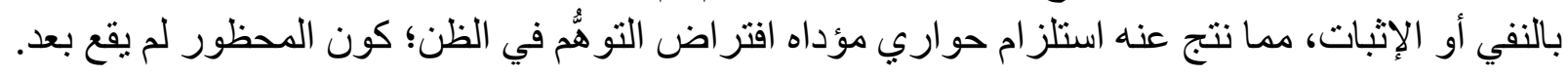

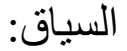

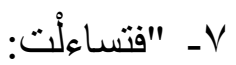

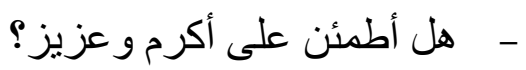

$$
\begin{aligned}
& \text { - لن يصيبهما مكروه.. اطمئن. } \\
& \text { - - مصفوان؟ } \\
& \text { - - سنصل إلى الحقيقة قريبًا. } \\
& \text { صمت برهة وقال: }
\end{aligned}
$$

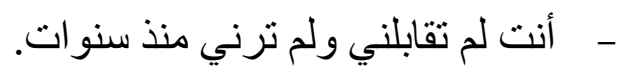

$$
\begin{aligned}
& \text { - }
\end{aligned}
$$

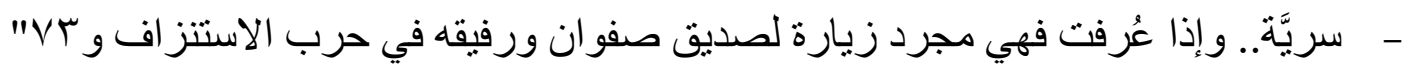

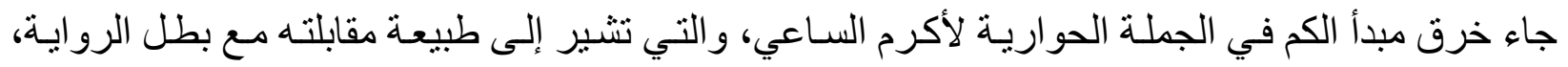

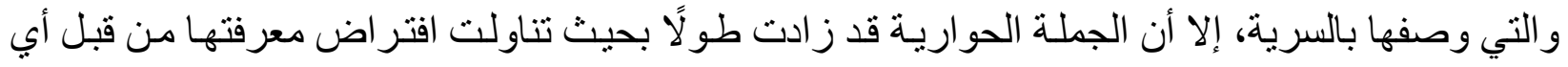

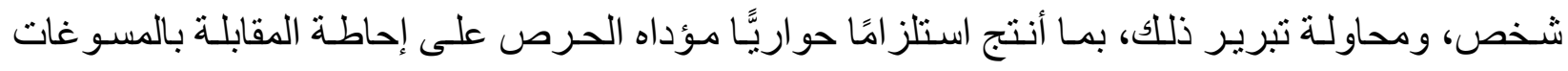
المقبولة لها. 


$$
\text { "اللغات بحوث " }
$$

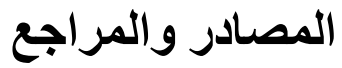

\section{أولاً : المصادر: \\ حسن البنداري:}

- رواية: صخب الهمس، مكتبة بورصة الكتب للنشر و التوزيع، القاهرة، طب، 11 لـrم.

- رواية: العائد بالحب، مكتبة بورصة الكتب للنشر و التوزيع، القاهرة، طس، 10 • ب م.

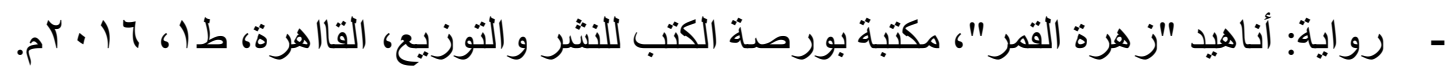

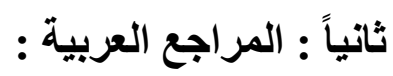

- طه عبد الرحمن: في أصول الحوار وتجديد علم الكلام، المركز الثقافي العربي، بيروت لبنان،

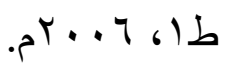

- محمود أحمد نحلة، ، آفاق جديدة في البحث اللغوي المعاصر، دار المعرفة الجديدة، القاهرة،

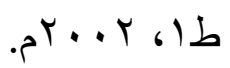

- نصر محمد عباس: الدلالات الرمزية وآفاق التوقع والانتظار في إبداعات حسن البنداري

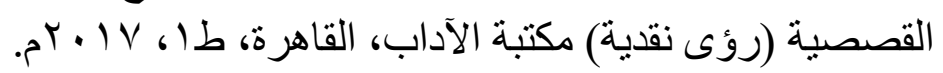




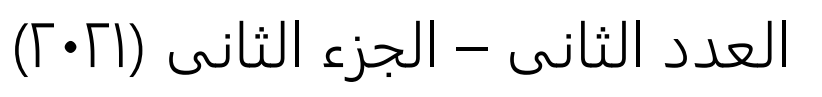

مجلة بحوث

"اللغات"

\title{
Violation of the principle of quantum talk in the trilogy of love for Hassan Al-Bendari
}

Prepared By

\section{Sara Mohamed Mustafa Ibrahim}

Supervised By

Dr.

Alaa Abdel Gaafar

Lecturer of Rhetoric and Literary

Criticism, Faculty of Girls for

Arts, Science and Education - Ain

Shams University
Prof. Dr.

Tariq Saad Shalabi

Professor of Rhetoric and Literary

Criticism, Department of Arabic

Language and Literature, Faculty of

Arts, Ain Shams University.

\begin{abstract}
This research deals with the breach of the discursive quantum principle in light of Grace's principles, and reached several results, namely:

The credit is due to the conceptualization and detail of the principles of entailment and laying down the methodological foundations for this aspect of the linguistic lesson, which is what the scholars built on from their visions and perceptions of the dialogue and its use in texts of various kinds.

- The dialogue entrenchment is achieved by violating one of the principles conceived by Grace, which makes speech meanings and connotations that are not apparent.

Grace built the quantum principle on two foundations: Your advice is as much as he needs, and you should not make your statement go beyond the required amount. This principle contributes to controlling the frank communication between the interlocutors in controlling the frank communication in an order that distracts speech from its outward appearance and refers to the clues that determine the meaning directed to it.

- Al-Bandaari's love trilogy fell in violation of the principles on its pages, which gave the fictional text a richness in connotations and positions and expresses the content of the characters, and this page defines the elements of the elements on the site
\end{abstract}

Key Words: Invoking dialogue, the writer Hassan Al-Bandari, his life and works, the love trilogy 